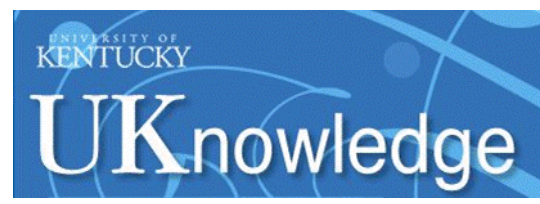

University of Kentucky

UKnowledge

$11-2015$

\title{
Hypercalcemia of Malignancy: An Update on Pathogenesis and Management
}

Aibek E. Mirrakhimov

University of Kentucky, ami276@uky.edu

Follow this and additional works at: https://uknowledge.uky.edu/internalmedicine_facpub

Part of the Medicine and Health Sciences Commons

Right click to open a feedback form in a new tab to let us know how this document benefits you.

\section{Repository Citation}

Mirrakhimov, Aibek E., "Hypercalcemia of Malignancy: An Update on Pathogenesis and Management" (2015). Internal Medicine Faculty Publications. 82.

https://uknowledge.uky.edu/internalmedicine_facpub/82

This Article is brought to you for free and open access by the Internal Medicine at UKnowledge. It has been accepted for inclusion in Internal Medicine Faculty Publications by an authorized administrator of UKnowledge. For more information, please contact UKnowledge@lsv.uky.edu. 


\section{Hypercalcemia of Malignancy: An Update on Pathogenesis and Management}

\section{Digital Object Identifier (DOI)}

http://dx.doi.org/10.4103/1947-2714.170600

\section{Notes/Citation Information}

Published in North American Journal of Medical Sciences, v. 7, no. 11, p. 483-493.

(C) 2015 North American Journal of Medical Sciences | Published by Wolters Kluwer - Medknow

This is an open access article distributed under the terms of the Creative Commons AttributionNonCommercial-ShareAlike 3.0 License, which allows others to remix, tweak, and build upon the work non-commercially, as long as the author is credited and the new creations are licensed under the identical terms. 
Review Article

\title{
Hypercalcemia of Malignancy: An Update on Pathogenesis and Management
}

\author{
Aibek E. Mirrakhimov \\ Department of Medicine, University of Kentucky School of Medicine, 800 Rose Street, Lexington, KY 40536, USA
}

\begin{abstract}
Hypercalcemia of malignancy is a common finding typically found in patients with advanced stage cancers. We aimed to provide an updated review on the etiology, pathogenesis, clinical presentation, and management of malignancy-related hypercalcemia. We searched PubMed/Medline, Scopus, Embase, and Web of Science for original articles, case reports, and case series articles focused on hypercalcemia of malignancy published from 1950 to December 2014. Hypercalcemia of malignancy usually presents with markedly elevated calcium levels and therefore, usually severely symptomatic. Several major mechanisms are responsible for the development of hypercalcemia of malignancy including parathyroid hormone-related peptide-mediated humoral hypercalcemia, osteolytic metastases-related hypercalcemia, 1,25 Vitamin D-mediated hypercalcemia, and parathyroid hormone-mediated hypercalcemia in patients with parathyroid carcinoma and extra parathyroid cancers. Diagnosis should include the history and physical examination as well as measurement of the above mediators of hypercalcemia. Management includes hydration, calcitonin, bisphosphonates, denosumab, and in certain patients, prednisone and cinacalcet. Patients with advanced underlying kidney disease and refractory severe hypercalcemia should be considered for hemodialysis. Hematology or oncology and palliative care specialists should be involved early to guide the options of cancer targeted therapies and help the patients and their closed ones with the discussion of comfort-oriented care.
\end{abstract}

Keywords: Cancer, hypercalcemia, parathyroid hormone related peptide, vitamin D

Address for correspondence: Dr. Aibek E. Mirrakhimov, Department of Internal Medicine, Saint Joseph Hospital, 290o North Lake Shore, Chicago, Illinois 60657, USA. E-mail: amirrakhimov1@gmail.com

\section{Introduction}

Hypercalcemia is defined as an increase in the serum calcium level above the upper limit of normal for a given reference value used in a laboratory. ${ }^{[1]}$ The differential diagnosis of hypercalcemia includes multiple pathologic entities but is focused primarily on primary hyperparathyroidism and hypercalcemia of malignancy given the highest prevalence of these etiologies. ${ }^{[1]} \mathrm{It}$ seems that hypercalcemia of malignancy is a common finding in patients with cancer, affecting up to $44.1 \%$ of patients. ${ }^{[2,3]}$ It is also important to note that hypercalcemia of malignancy is particularly common in cases of

Access this article online

\begin{tabular}{l|l}
\hline Quick Response Code: & Website: \\
& www.najms.org \\
\hline & \\
&
\end{tabular}

advanced stage cancer. ${ }^{[4]}$ Patients with hypercalcemia of malignancy tend to have limited survival of several months, and it is not clear whether this poor prognosis is related to the advanced stage of malignancy associated hypercalcemia or just simply a marker of underlying cancer. ${ }^{[5]}$

It is unclear whether asymptomatic hypercalcemia heralds the later development of cancer. To answer this question, Hamilton et al. retrospectively analyzed the

This is an open access article distributed under the terms of the Creative Commons Attribution-NonCommercial-ShareAlike 3.0 License, which allows others to remix, tweak, and build upon the work non-commercially, as long as the author is credited and the new creations are licensed under the identical terms.

For reprints contact: reprints @ medknow.com

How to cite this article: Mirrakhimov AE. Hypercalcemia of malignancy: An update on pathogenesis and management. North Am J Med Sci 2015;7:483-93. 
charts of more than 52,000 patients. ${ }^{[6]}$ The goal of their work was to study whether a finding of elevated calcium can predate the development of malignancy. Patients with hypercalcemia comprised the minority but had higher rates of cancer diagnosis at 1 -year $(6.2 \%$ compared to $3.0 \%)$. However, the retrospective methodology of this study should be kept in mind when interpreting the study results. Another important aspect to mention briefly is that not all hypercalcemia in cancer patients is secondary to malignancy, and this is discussed further in subsequent sections. ${ }^{[7]}$

The goal of this study is to review the current knowledge on the etiopathogenesis, clinical presentation, diagnosis, and treatment of hypercalcemia of malignancy. We searched PubMed/Medline, Scopus, Embase, and Web of Science for original articles, case reports, and case series articles focused on hypercalcemia of malignancy published from 1950 to December 2014. The search terms were: Hypercalcemia of malignancy, hypercalcemia, Vitamin D and hypercalcemia, skeletal metastases and hypercalcemia, parathyroid hormone (PTH), PTH-related peptide (PTHrP), and the combination of these. The reference lists of the identified articles were further screened for potentially relevant articles that could be overlooked by an electronic search. The search methodology was adapted from the scientific search guidelines published in 2011. ${ }^{[8]}$ We start with a physiological overview of calcium metabolism. Second, we discuss the etiology and pathogenesis of hypercalcemia of malignancy. Third, we review the clinical presentation of hypercalcemia. Fourth, the diagnostic approach to hypercalcemia is addressed. Finally, the management of hypercalcemia of malignancy is discussed.

\section{Normal Regulation of Calcium Metabolism}

Calcium is an essential element that participates in various biochemical reactions, including muscle contraction, coagulation and bone development among others. ${ }^{[9]}$ Calcium is absorbed predominantly in the small intestine, and it is necessary to note that only $10-20 \%$ of ingested calcium is absorbed, the remainder being excreted with the stool. ${ }^{[9]}$ Calcium in the body is present in two major compartments: Bone, where calcium is stored as hydroxyapatite salt that comprises the major part of body calcium, and plasma. ${ }^{[10]}$ In plasma, serum calcium is present in several forms, such as free or ionized calcium, which is actually a physiologically active form corresponding to approximately $45 \%$ of serum calcium, with $65 \%$ of calcium being bound to various carriers, such as albumin ( $40 \%$ of calcium), citric acid, sulfate, and phosphate. ${ }^{[10]}$

Several hormonal systems regulate calcium absorption and metabolism. When calcium levels drop below
$10 \mathrm{mg} / \mathrm{dl}$, this activates calcium-sensing cells in the parathyroid glands to stimulate the release of PTH. PTH release reaches a peak when calcium falls below $7.5 \mathrm{mg} / \mathrm{dl}{ }^{[9]}$ When the calcium level is above $10 \mathrm{mg} / \mathrm{dl}$, the secretion of PTH is minimal. PTH has several important actions focused on the increase of serum calcium. First, PTH activates the 1-alpha-hydroxylase enzyme located in the renal proximal tubules, which in turn converts 25-hydroxyvitamin D into the more active 1,25-dihydroxyvitamin D. ${ }^{[10]}$ Second, PTH stimulates calcium reabsorption in the distal part of the nephron (thick ascending limb of the loop of Henle and distal convoluted tubule) and renal phosphorus excretion. Third, PTH leads to calcium mobilization from the bone with the help of 1,25-dihydroxyvitamin D. All these actions aim to increase calcium concentrations, bringing them back to normal.

Another key player in normal calcium metabolism is Vitamin D. Vitamin D or cholecalciferol sources in the body include synthesis in the skin from 7-dehydrocalciferol under the influence of ultraviolet light and dietary intake. ${ }^{[10]}$ Subsequently, 25-hydroxycholecalciferol will be converted into 25-dihydroxycholecalciferol in the liver by 25-hydroxyvitamin D3 1-alpha-hydroxylase. Eventually, 25-dihydroxycholecalciferol will be delivered into kidneys where it can be activated by the aforementioned 1-alpha-hydroxylase enzyme (which is activated by PTH) into 1,25-dihydroxycholecalciferol. ${ }^{[10]}$ 1,25-dihydroxycholecalciferol in turn increases the absorption of calciumand phosphatein thegastrointestinal tract, decreases the renal excretion of calcium and phosphate, and with the participation of PTH leads to increased calcium release from the bone and subsequent bone mineralization. ${ }^{[9]}$ It is important to note that 1,25-dihydroxycholecalciferol is deactivated by the 24,25 -hydroxylase enzyme in the kidneys. ${ }^{[10]}$

From a normal physiology perspective, it is important to mention a thyroid hormone, calcitonin, which is produced by thyroid C cells. ${ }^{[10]}$ Calcitonin release is augmented when calcium concentration increases and limits bone remodeling and subsequent calcium release from the bone and calcium reabsorption in the kidneys. However, tumors secreting calcitonin, such as medullary thyroid cancer, do not lead to low calcium levels. ${ }^{[10]}$ Nevertheless, calcitonin may be used in the management of hypercalcemia of malignancy (as discussed below). A possible explanation for the efficacy of calcitonin in patients with malignancy-related hypercalcemia could be related to secondary overzealous bone resorption and calcium release in these patients.

Finally, it is necessary to discuss briefly the different roles of major bone cells and their interplay in bone turnover 
and calcium release. For this purpose, we focus on two cellular types: Osteoblasts and osteoclasts. Osteoblasts derive from mesenchymal cells and osteoclasts originate from monocyte lineage that migrates into the bone environment from the bloodstream. ${ }^{[10,11]}$ Osteoclast precursor cells carry the receptor activator of nuclear factor-K B (RANK). ${ }^{[10,11]}$ Osteoblasts in turn secrete a ligand for RANK (RANKL), which stimulates the maturation of osteoclast precursors and the formation of mature osteoclasts capable of bone remodeling and calcium release. ${ }^{[11,12]}$ Factors that promote bone remodeling and calcium release from the bone stimulate osteoblasts through RANKL release and subsequent activation of osteoclasts. Factors that exert the opposite effects on bone turnover (such as estrogens) stimulate the release of osteoprotegerin from osteoblasts, binding RANKL, and preventing it from binding to RANK on the osteoclast precursor cell. ${ }^{[12-14]}$

In conclusion, the intricate interaction between calcium levels, PTH, Vitamin D, and bone cells regulates bone metabolism and calcium release from the bones.

\section{Etiology and Pathobiology of Hypercalcemia of Malignancy}

There are several major mechanisms of hypercalcemia of malignancy, which are discussed here. First, the major mechanism, accounting for approximately $80 \%$ of malignancy-related hypercalcemia, is mediated by the production of PTHrP.$^{[4]}$ It is also important to note that PTHrP is normally produced and secreted by various cells, and normal breast cells in particular. ${ }^{[15]}$ Furthermore, PTHrP under normal physiological conditions participates in the development of various tissues, facilitates transplacental calcium transport, and promotes calcium transfer to breast milk. ${ }^{[15]}$ Both PTH and PTHrP act on the same receptors and their effects consistently overlap. Indeed, the biochemical structure of PTHrP greatly resembles that of PTH. ${ }^{[15]}$ However, PTHrP does not seem to have a major influence on the production of 1,25-dihydroxycholecalciferol. ${ }^{[15]}$ Therefore, PTHrP acts on osteoblasts, leading to enhanced synthesis of RANKL, with subsequent activation of osteoclasts and bone resorption with calcium release into the bloodstream. Increased renal calcium reabsorption is another mechanism through which PTHrP leads to hypercalcemia. Squamous cell cancers, urinary tract cancers (renal cancer and bladder cancer), breast cancer, nonHodgkin's lymphoma, and ovarian cancer account for the majority of malignancies leading to hypercalcemia via PTHrP. ${ }^{[4]}$

The second mechanism by which malignancies cause hypercalcemia includes osteolytic metastases and excessive calcium release from bone, accounting for approximately $20 \%$ of malignancy-related hypercalcemia ${ }^{[4]}$ Breast cancer and multiple myeloma account for the vast majority of the cases of osteolytic hypercalcemia. ${ }^{[4]}$ It is interesting to note that metastatic breast cancer cells may produce PTHrP locally, without a major increase in serum PTHrP. ${ }^{[16]}$ Local factors that are released in the presence of metastatic bone lesions include transforming growth factor $\beta$, which stimulates PTHrP to be produced locally from metastatic breast cancer cells. ${ }^{[17]}$ In turn, the elevation of calcium further stimulates local PTHrP release, generating a vicious cycle. In the case of multiple myeloma, the local release of various cytokines, such as RANKL, interleukin-3 and -6 , facilitate bone remodeling and resultant hypercalcemia. ${ }^{[18]}$ It is worth noting that a very small proportion of patients with multiple myeloma and hypercalcemia do not have true hypercalcemia. ${ }^{[19]}$ This apparent increase in calcium is mediated by calcium binding to paraprotein secreted by multiple myeloma cells. ${ }^{[19]}$ It should be borne in mind that such patients will typically have a mild elevation in total calcium with normal ionized levels and will not have any symptoms of hypercalcemia.

The third mechanism includes ectopic activity of 1-alpha-hydroxylase and the formation of 1,25-dihydroxycholecalciferol, common in lymphomas and in some ovarian germ cell tumors. ${ }^{[4]}$ The fourth mechanism by which cancer can lead to hypercalcemia includes ectopic production of $\mathrm{PTH}^{\left[{ }^{[20]}\right.}$ or in rare cases PTH can be secreted by parathyroid carcinoma. ${ }^{[21]}$ Small cell lung cancer and adenocarcinoma can mediate hypercalcemia via such mechanism. ${ }^{[20]}$ Furthermore, it is important to note that some patients with apparent hypercalcemia of malignancy will have evidence of primary hyperparathyroidism. ${ }^{[22-24]}$

In conclusion, there are several major mechanisms that account for malignancy-related hypercalcemia, including the excessive tumor production of PTHrP, osteolytic metastatic disease, ectopic activity of 1-alpha-hydroxylase and the production of 1,25-dihydroxycholecalciferol, the excessive production of PTH by parathyroid carcinoma and extra parathyroid malignancies, and finally hypercalcemia due to paraprotein binding. The major mechanisms of malignancy-related hypercalcemia are emphasized in Figure 1.

\section{Clinical Presentation of Hypercalcemia}

For a long time, clinicians used mnemonics, such as "stones, bones, abdominal moans, and psychic groans" to memorize the major clinical manifestations of hypercalcemia. ${ }^{[4]}$ Indeed, the major systems affected by hypercalcemia include neuropsychiatric, gastrointestinal, and renal. It is important to note that at least two factors 
play a role in the development of clinically overt hypercalcemia, such as the degree of hypercalcemia and the rapidity of its development. Patients with hypercalcemia of malignancy typically have a higher degree of hypercalcemia and develop it over a shorter period, which is why these patients are usually more symptomatic than patients with other etiologies of hypercalcemia. ${ }^{[4]}$

Neurocognitive symptoms of hypercalcemia may include some behavioral disturbances, such as anxiety, mood changes and a decrease in cognitive function, which are typical of milder cases of hypercalcemia (degrees of hypercalcemia are discussed further in the next section). However, as patients with cancer generally present with higher values of calcium, they may develop more severe presentations, such as changes in mental status, including coma. ${ }^{[25]}$ Furthermore, patients with malignancy-related hypercalcemia may develop a syndrome of posterior reversible leukoencephalopathy (PRES), which is characterized clinically by the development of headaches, seizures and imaging findings of subcortical edema. ${ }^{[26,27]}$ Several pathobiological factors such as cerebral vasoconstriction, endothelial dysfunction, and systemic inflammation may precipitate PRES in such groups of patients. ${ }^{[27]}$

Renal manifestations of hypercalcemia consist of nephrogenic diabetes insipidus with resultant polyuria, renal vasoconstriction, distal renal tubular acidosis, and in more chronic cases, nephrolithiasis, tubular dysfunction, and chronic renal failure. ${ }^{[28,29]}$

Elevated calcium levels also affect the gastrointestinal system. Mild elevation of calcium may present as anorexia and constipation. ${ }^{[1]}$ Patients with more advanced hypercalcemia may develop nausea and vomiting. Thus, all patients with clinically overt hypercalcemia are volume depleted, which is explained by the renal effects of hypercalcemia (polyuria) and the decreased oral intake with associated nausea and vomiting. Other possible gastrointestinal manifestations of hypercalcemia include pancreatitis and peptic ulcer disease. ${ }^{[30,31]}$ However, it is important to note that peptic ulcer disease has predominantly been reported in hypercalcemia due to primary hyperparathyroidism. ${ }^{[30]}$ Nevertheless, clinicians should bear in mind this potential complication in a patient with hypercalcemia and clinical findings suggestive of upper gastrointestinal bleeding (such as black tarry stools or frank bloody stools, epigastric pain, dropping hematocrit, and hemodynamic instability).

Another organ system that may be affected by elevated calcium is the cardiovascular system. Patients with hypercalcemia typically have a shortened QT interval on the electrocardiogram (ECG). ${ }^{[32]}$ Severe hypercalcemia may mimic ST-segment elevation myocardial infarction on the ECG. ${ }^{[3-35]}$ Cardiac catheterization has been found to be negative for coronary atherosclerosis ${ }^{[32,33]}$ and in one case, myocardial infarction has been ruled out with serial cardiac enzymes (troponin and creatine kinase-MB fraction) measurements. ${ }^{[34]}$ Furthermore, patients with severe hypercalcemia may develop malignant ventricular arrhythmias such as ventricular fibrillation. ${ }^{[36]}$

Also, it is important to bear in mind that most patients with malignancy-related hypercalcemia have clinically overt cancer (either retrospectively or newly diagnosed). Therefore, in a patient without documented malignancy but with severe newly diagnosed hypercalcemia, it is important to take a focused history (e.g., smoking history, exposure to carcinogens, family history of cancer, prior personal history of cancer, presence of cough, unintentional weight loss, etc.), and perform a thorough physical examination (e.g., breast mass in a female patient, abdominal mass on palpation, etc.) in order to guide a further diagnostic work-up. A summary of the clinical features of hypercalcemia is presented in Table 1.

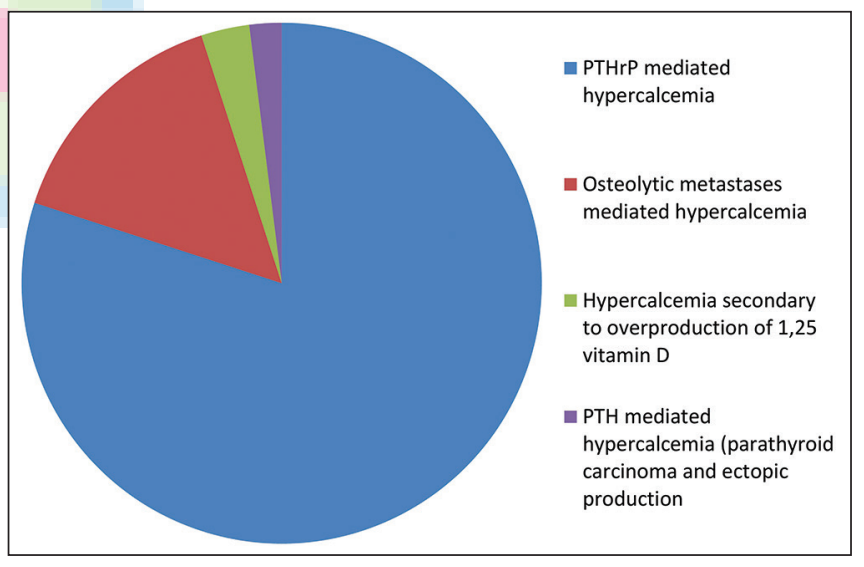

Figure 1: Etiobiology of hypercalcemia of malignancy

\begin{tabular}{ll}
\hline Table 1: Clinical features of hypercalcemia \\
\hline Organ system & Clinical features \\
\hline Neurologic & $\begin{array}{l}\text { Fatigue, altered mental status } \\
\text { including coma, posterior reversible } \\
\text { leukoencephalopathy }\end{array}$ \\
Gastrointestinal & $\begin{array}{l}\text { Nausea, vomiting, constipation, peptic ulcer } \\
\text { disease, and pancreatitis }\end{array}$ \\
Cardiovascular & $\begin{array}{l}\text { Short QT interval on ECG, ST segment } \\
\text { abnormalities including ST segment } \\
\text { myocardial infarction mimic, malignant } \\
\text { ventricular arrhythmias, and hypertension }\end{array}$ \\
Renal & $\begin{array}{l}\text { Nephrogenic diabetes insipidus, acute } \\
\text { kidney injury }\end{array}$ \\
\hline
\end{tabular}

ECG $=$ Electrocardiogram 


\section{Diagnostic Approach to Hypercalcemia}

As discussed above, serum calcium is the sum of carrier-bound calcium that is not physiologically active and ionized calcium, which is the active form of serum calcium. ${ }^{[9]}$ Thus, when evaluating elevated serum calcium levels, it is essential to keep this in mind, especially as most general chemistry tests measure total calcium rather than free ionized calcium. Therefore, conditions in which the alteration of serum protein levels is a feature may have abnormal total calcium levels, but may not have any changes in physiologically important ionized calcium levels. ${ }^{[37]}$ For example, malnourished patients or patients with a protein-losing condition (e.g., nephrotic syndrome, protein-losing enteropathy, etc.) may be found to have low total calcium levels due to a decrease in albumin levels, a major carrier for calcium in the blood (it is possible that some patients with low total calcium may have elevated ionized calcium due to underlying conditions such as cancer). On the other hand, patients with severe dehydration may have elevated protein levels and hence, elevated calcium levels. ${ }^{[37]}$

Therefore, it is advised to confirm elevated serum calcium with a repeat test. Nevertheless, it is reasonable to start treatment with intravenous (IV) fluid hydration for markedly elevated calcium levels, especially with associated typical symptoms, while awaiting a repeat calcium measurement. Several approaches can be used to distinguish between true hypercalcemia and pseudohypercalcemia. First, it is possible to estimate the levels of free or ionized calcium after adjustment for albumin levels. Correction of calcium for albumin level should be done in patients with abnormal (both low and elevated levels) albumin and can be calculated via this formula: Calcium $(\mathrm{mg} / \mathrm{dl})+0.8(4.0$ - patient's albumin level); however, numerous free online calculators are available which can be used in clinical practice. Second, it is possible to measure ionized calcium levels directly, and this may be the preferred method given its higher sensitivity, as albumin is the major but not the only carrier. ${ }^{[38]}$ Most laboratories in the United States of America use a range of total serum calcium levels of $8.5-10.2 \mathrm{mg} / \mathrm{dl}$ (please follow your institution's range for serum calcium). We divide hypercalcemia into mild hypercalcemia with serum calcium levels $<12 \mathrm{mg} / \mathrm{dl}$, moderate hypercalcemia with serum calcium levels between $12 \mathrm{mg} / \mathrm{dl}$ and $14 \mathrm{mg} / \mathrm{dl}$, and severe hypercalcemia with serum calcium levels above $14 \mathrm{mg} / \mathrm{dl}$.

From a clinical perspective, most cases of hypercalcemia are due to cancer or primary hyperparathyroidism. ${ }^{[1,37]}$ However, as already discussed, most patients with cancer have greater levels of calcium than patients with hypercalcemia secondary to other causes and are more symptomatic. Furthermore, the diagnosis of cancer will be obvious in a great number of cases. Nevertheless, from the conceptual perspective, hypercalcemia can be divided into PTH-dependent and PTH-independent (after confirmation of truly elevated calcium). ${ }^{[1,37]}$ PTH-dependent causes largely include primary hyperparathyroidism, PTH production by malignant cells (parathyroid carcinoma and extra parathyroid cancers) and familial hypocalciuric hypercalcemia. ${ }^{[1,37]}$ Other causes of hypercalcemia (including cancer-related) constitute PTH-independent hypercalcemia.

The next step in evaluating a case with suspicious features of malignancy-related hypercalcemia consists of measuring both PTH and PTHrP. The reason for the PTH measurement in such cases includes the fact that patients with cancer may have a greater prevalence of primary hyperparathyroidism, and some patients with cancer may have primary hyperparathyroidism as a sole cause of hypercalcemia. ${ }^{[7,22,39]}$ In cases in which malignancy is the only cause of hypercalcemia, serum PTH levels should be suppressed or low normal. High normal PTH levels in the setting of hypercalcemia are inappropriate and suggest the presence of parathyroid hyperfunction. ${ }^{[1,37]}$ Given the fact that some cancers may produce PTH ectopically, ${ }^{[20,40]}$ imaging tests may be used to evaluate the parathyroid glands for hyperfunction in selected cases ${ }^{[41,42]}$ PTHrP levels will be elevated in cases of humoral hypercalcemia of malignancy. However, in some cases, in which the diagnosis of cancer (e.g., known advanced squamous cell carcinoma of the lung) is well known, the measurement of PTHrp levels may be omitted. From a management perspective, the degree of PTHrP elevation may predict response to bisphosphonates and mortality. ${ }^{[43-46]}$

If the PTHrP levels are low, the next step should include measurement of 1,25-dihydroxyvitamin D levels to screen for Vitamin D-mediated hypercalcemia, which is typically seen in lymphomas. In patients with low levels of PTH, PTHrp, and 1,25-dihydroxyvitamin D, one might consider hypercalcemia due to osteolytic metastases as the cause of malignancy-related hypercalcemia. However, it is important to note that more than one mechanism of malignancy-associated hypercalcemia can be seen in a particular patient. ${ }^{[4]}$

Furthermore, an approach to hypercalcemia should be thorough and include the review of medications. ${ }^{[1,37]}$ Medications such as lithium, thiazide diuretics, and Vitamin A and D supplements should be discontinued if possible. These medications might not explain the hypercalcemia, but have the potential to make it worse.

In conclusion, an approach to hypercalcemia consists of confirming that hypercalcemia is true. Second, 
measurements of PTH and PTHrp should start the laboratory work-up. Serum 1,25-dihydroxyvitamin D measurement should be undertaken when OTH and PTHrp are decreased. Hypercalcemia secondary to osteolytic metastases should be considered when the laboratory values mentioned above are decreased. Furthermore, a review of home medications should be done and the discontinuation of medications capable of causing hypercalcemia should be considered. A diagnostic flowchart is presented in Figure 2.

\section{Management of Hypercalcemia}

The management of hypercalcemia is based on the presence of characteristic symptomatology and the severity of calcium elevation. Patients with hypercalcemia of malignancy are typically symptomatic and have markedly elevated calcium levels. Thus, patients with hypercalcemia will generally need to be managed with urgency, and hypercalcemia of malignancy in many cases represents an oncologic emergency.

The treatment options for hypercalcemia include IV hydration, calcitonin, bisphosphonates, denosumab, gallium nitrate, prednisone, and hemodialysis. Each therapeutic modality is discussed in greater detail in this section. It is also important to emphasize that given the overall poor prognosis of many patients with malignancy-related hypercalcemia, a palliative care team should be involved in the care of the patient and the goals of care should be discussed with the patient or his or her surrogate.

As discussed above, patients with hypercalcemia are dehydrated by default due to poor oral intake secondary to nausea, vomiting, altered mental status, and hypercalcemia-induced nephrogenic diabetes insipidus.

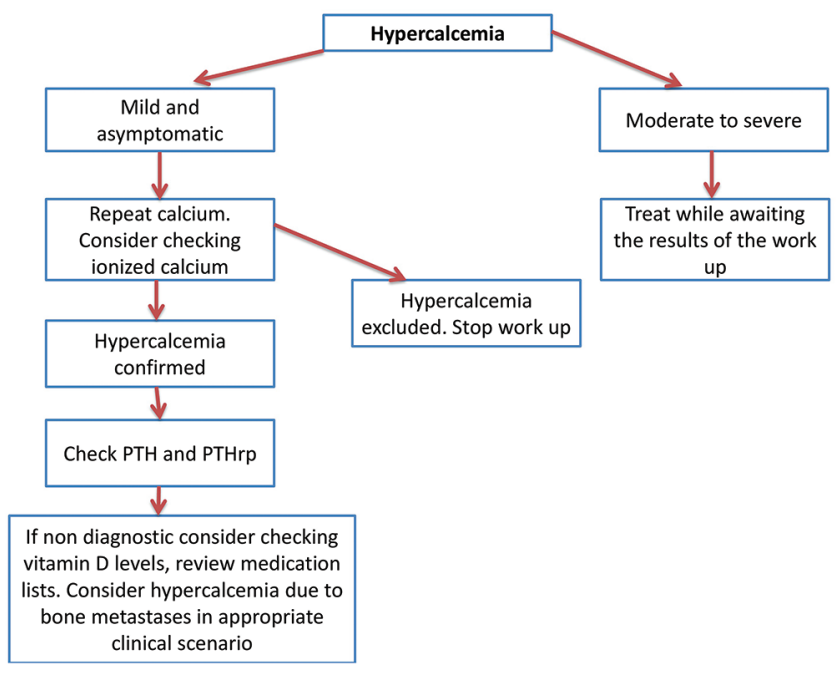

Figure 2: Diagnostic flowchart on the work up of hypercalcemia
Furthermore, volume contraction in itself compromises renal clearance of calcium due to hypovolemia-mediated increased calcium reabsorption in the kidneys. ${ }^{[47]}$ Several factors, such as the presence of underlying cardiorenal disease, should be borne in mind when considering IV hydration. Isotonic crystalloid solutions (e.g., normal saline) should be used for IV hydration. ${ }^{[48]}$ We typically start patients with advanced hypercalcemia at a rate of around $200-300 \mathrm{ml} / \mathrm{h}$ and reassess them periodically for signs of fluid overload (shortness of breath, edema, etc.). The rate of IV hydration should be decreased in patients with underlying cardiac and renal disease to minimize the risk of symptomatic fluid overload. It is important to mention that the routine use of loop diuretics such as furosemide is not recommended due to the development of volume depletion and electrolyte abnormalities. ${ }^{\left[{ }^{[9]}\right]}$ Moreover, there are much more specific therapies targeting hypercalcemia. The use of furosemide should be reserved for patients who develop signs of fluid overload while receiving IV hydration.

However, IV hydration alone is not enough to correct severe hypercalcemia. The second option that should be considered in the management of severe hypercalcemia is calcitonin. ${ }^{[50]}$ It is important to emphasize that only intramuscular or subcutaneous administration should be used given the fact that intranasal calcitonin does not seem to be effective in hypercalcemia for reasons that are not yet clear. ${ }^{[51]}$ The typical dose of calcitonin for the management of hypercalcemia ranges from $4 \mathrm{IU} / \mathrm{kg}$ to $8 \mathrm{IU} / \mathrm{kg} .{ }^{[50,52]}$ The drop in serum calcium typically occurs within $4 \mathrm{~h}$ after administration and one should expect a maximal drop in calcium of $2 \mathrm{mg} / \mathrm{dl} . .^{[50,52]}$ The dosing intervals range from every $6 \mathrm{~h}$ to every $12 \mathrm{~h}$. It is important to note that both the dose and administration frequency are tailored to the hypocalcemic response. The duration of administration is typically limited to $48 \mathrm{~h}$ given the development of tachyphylaxis and decreased responsiveness. ${ }^{[50,52]}$ Calcitonin seems to work via the inhibition of osteoclast activity and an increase in renal calcium excretion. ${ }^{[53]}$ Calcitonin is an important adjunctive medication in the management of severe hypercalcemia given its rapid onset of action and serves as a bridge while other treatment modalities are reaching its therapeutic effect.

Bisphosphonates comprise a group of medications that are analogs of natural pyrophosphate, which is an essential part of bones. ${ }^{[5,55]}$ Bisphosphonates are used in many situations, such as the treatment and prevention of osteoporosis, Paget's disease of bone, metastatic bone disease, and hypercalcemia. This section discusses the use of bisphosphonates in the management of symptomatic hypercalcemia, particularly hypercalcemia of malignancy. For greater detail on the role of bisphosphonates in the management of other 
diseases, the reader is referred to review articles on this topic. ${ }^{[5,55]}$ Bisphosphonates are typically subdivided into two groups: First generation and second-generation. The first-generation or nonnitrogen-containing bisphosphonates include etidronate and clodronate, which are less commonly used nowadays..$^{[54,55]}$ The secondgeneration or nitrogen-containing bisphosphonates include such medications as alendronate, risedronate, ibandronate, pamidronate, and zoledronic acid, which are generally more potent than the first-generation bisphosphonates. The mechanisms of action include the impairment of osteoclast-mediated bone resorption, the arrest of osteoclast development, osteoclast apoptosis, and a decrease in osteoblast apoptosis. ${ }^{[5,55]}$

Zoledronic acid, ibadronate, pamidronate, and less often etidronate are used for the treatment of hypercalcemia of malignancy. Zoledronic acid is the most potent agent among the bisphosphonates, as shown in a study that compared zoledronic acid to pamidronate. ${ }^{[56]}$ The typical dose is $4 \mathrm{mg}$ administered IV over $15-30 \mathrm{~min}$. Pamidronate and ibandronate are less potent agents than zoledronic acid but have similar efficacy when compared to each other ${ }^{[57]}$ The typical dose range for pamidronate is from $60 \mathrm{mg}$ to $90 \mathrm{mg}$ administered IV over 2 to $24 \mathrm{~h}$. However, a shorter duration of pamidronate administration, such as $4 h$, may be as safe as the longer duration of administration. ${ }^{[58]}$ Ibandronate has a dose range from $2 \mathrm{mg}$ to $6 \mathrm{mg}$ administered IV, but it is important to mention that the use of ibandronate is off-label for the treatment of hypercalcemia. ${ }^{[57]}$ These drugs have been used in patients with underlying kidney dysfunction and hypercalcemia of malignancy. For example, zoledronic acid has been used in patients with creatinine of $4.5 \mathrm{mg} / \mathrm{dl}^{[56]}$ and pamidronate in patients with creatinine of $1.5 \mathrm{mg} / \mathrm{dl}$ and higher. ${ }^{[59]}$ Nevertheless, it is advised to decrease the doses and duration of administration in patients with underlying renal disease. However, bisphosphonates seem to be safe in patients with end-stage renal disease on hemodialysis. ${ }^{[60,61]}$ The onset of the calcium-lowering effect is within 2-4 days after the administration.

Bisphosphonates are usually well-tolerated, but several classic side effects have been described. Patients taking bisphosphonates commonly experience flu-like symptoms; other potential side effects include ocular symptoms, acute kidney injury, new-onset nephrotic syndrome, esophageal inflammation (typically for orally administered drugs), and very rarely osteonecrosis of the jaw. ${ }^{[54,55]}$ Osteonecrosis of the jaw is typically reported in patients with multiple myeloma or metastatic bone disease receiving high potency bisphosphonates, such as zoledronic acid and denosumab, which is a monoclonal antibody to RANKLL. ${ }^{[62]}$ However, patients who develop this complication typically receive the aforementioned medications for at least 4 months. Thus, osteonecrosis of the jaw is not typically a problem during acute management of hypercalcemia of malignancy. It is important to mention that bisphosphonates are given once, and the dose should be repeated no earlier than 1 -week after the administration of the first dose. Moreover, as mentioned above, patients with marked elevation of PTHrP may be more resistant to the hypocalcemic effects of bisphosphonates. ${ }^{[43-46]}$

Denosumab is a human monoclonal antibody to RANKL, thus working through decreasing osteoclast activity and bone resorption. ${ }^{[63]}$ Denosumab has been shown to be effective in hypercalcemia refractory to bisphosphonates. ${ }^{[21,64-66]}$ Furthermore, denosumab has an advantage to bisphosphonates in that it is not removed by the kidneys. It is important to mention that denosumab has been shown to improve renal function in patients with multiple myeloma and hypercalcemia. ${ }^{[67,68]}$ However, the effect of denosumab may be more pronounced in patients with renal failure, and some have suggested a lower dose (half) in the case of renal failure. ${ }^{[68]}$ The typical dose of denosumab is $120 \mathrm{mg}$ subcutaneously, and the dose should be repeated no earlier than 1-week following the first administration. ${ }^{[69]}$ The hypocalcemic effect of denosumab is typically seen within 2-4 days after the administration. The use of denosumab for the management of hypercalcemia of malignancy is off-label and should be reserved for cases of severe hypercalcemia refractory to more conventional treatment.

Common side effects attributed to denosumab include bone pain, nausea, diarrhea, shortness of breath, and in rare instances osteonecrosis of the jaw, which is usually seen in patients treated with denosumab for at least several months, thus making it less important in the acute setting of hypercalcemia of malignancy. ${ }^{[62,63]}$ Data on denosumab and infectious risk are controversial, but a major clinical study failed to demonstrate an infectious risk in patients treated with denosumab. ${ }^{[70]}$

Patients with lymphomas and some ovarian germ tumors who overproduce 1,25-dihydroxycholecalciferol can be treated with prednisone to reduce the gastrointestinal absorption of calcium. ${ }^{[71]}$ The typical dose of prednisone is 20-40 mg orally. ${ }^{[71]}$ Common side effects of prednisone use include hyperglycemia, hypertension, psychiatric disturbances, muscle weakness, peptic ulcer disease, and many others. ${ }^{[72]}$

Other pharmacological options for the treatment of hypercalcemia include cinacalcet and gallium nitrate. Cinacalcet works by decreasing the production of $\mathrm{PTH}^{[73]}$ and is commonly used in the management of hypercalcemia secondary to parathyroid carcinoma. ${ }^{[73,74]}$ It is unclear whether it can be used in a rare extra parathyroid cancer patient with ectopic production of 
PTH. The typical dose range of cinacalcet is from $60 \mathrm{mg}$ to $360 \mathrm{mg}$ orally, and the dose is typically split throughout the day. Common side effects include nausea, vomiting, and headaches.

Lastly, gallium nitrate can be used in the treatment of malignancy-related hypercalcemia via the inhibition of osteoclast activity and by increasing the renal calcium clearance. ${ }^{[75-77]}$ The typical dose used in the clinical studies is $200 \mathrm{mg} / \mathrm{m}^{2}$ administered as a slow IV infusion daily for 5 days. ${ }^{[7,79]}$ Gallium nitrate has been shown to be more potent than calcitonin, notably in a study of 164 patients with cancer-related hypercalcemia. ${ }^{[78]}$ The medication was well tolerated with a small percentage of treatment-related anemia and acute kidney injury being observed. ${ }^{[78,79]}$ However, gallium nitrate production was discontinued by the manufacturer in 2012, making it unavailable for the treatment of malignancy-related hypercalcemia.

Finally, patients with refractory severe hypercalcemia and underlying cardiorenal diseases that cannot safely be hydrated should be considered for hemodialysis. ${ }^{[80,81]}$
It is also important to consult with a hematologist or oncologist regarding the cancer-targeted treatment options for every patient, and a palliative care professional to improve the patient's symptoms and explore comfort care options in the right clinical scenario.

In conclusion, the treatment of symptomatic malignancy-related hypercalcemia should start with aggressive IV hydration in patients without significant renal or cardiac disease. Calcitonin can be used given its prompt effect and favorable side-effect profile. Bisphosphonates should be administered concurrently as the hypocalcemic effect starts within 2-4 days. Prednisone can be used in patients with an overproduction of 1,25-dihydroxycholecalciferol and cinacalcet should be considered in patients with an overproduction of PTH (e.g., parathyroid carcinoma). Patients with refractory hypercalcemia should be considered for denosumab therapy and lastly for hemodialysis. A summary of the therapeutic options for the treatment of hypercalcemia is presented in Table 2.

\begin{tabular}{|c|c|c|c|c|c|}
\hline Agent & Typical dose & $\begin{array}{l}\text { Mechanism of } \\
\text { action }\end{array}$ & $\begin{array}{l}\text { Modification based on } \\
\text { underlying renal and } \\
\text { liver disease }\end{array}$ & Onset of action & $\begin{array}{l}\text { Common side } \\
\text { effects }\end{array}$ \\
\hline Normal saline & $\begin{array}{l}\text { 200-300 milliners/ } \\
\text { hour, lower rate } \\
\text { in patients with } \\
\text { underlying cardiac } \\
\text { and kidney disease }\end{array}$ & $\begin{array}{l}\text { Volume } \\
\text { repletion, } \\
\text { increased renal } \\
\text { calcium clearance }\end{array}$ & $\begin{array}{l}\text { Consider lower rate in } \\
\text { patients with underlying } \\
\text { renal disease }\end{array}$ & $\begin{array}{l}\text { Within hours of } \\
\text { administration }\end{array}$ & $\begin{array}{l}\text { Volume overload, } \\
\text { non-anion } \\
\text { gap metabolic } \\
\text { acidosis }\end{array}$ \\
\hline Calcitonin & $\begin{array}{l}\text { 4-8 international } \\
\text { units } / \mathrm{kg} \\
\text { subcutaneously or } \\
\text { intramuscularly }\end{array}$ & $\begin{array}{l}\text { Inhibition of } \\
\text { osteoclast activity } \\
\text { and increase in } \\
\text { renal calcium } \\
\text { clearance }\end{array}$ & $\begin{array}{l}\text { No dosage adjustment is } \\
\text { needed }\end{array}$ & $\begin{array}{l}\text { Within } 4 \mathrm{~h} \text { of } \\
\text { administration. } \\
\text { Tachyphylaxis } \\
\text { develops after } 48 \mathrm{~h}\end{array}$ & $\begin{array}{l}\text { Nausea, rhinitis, } \\
\text { hypersensitivity } \\
\text { reactions }\end{array}$ \\
\hline Bisphosphonates & $\begin{array}{l}\text { Zoledronic acid } 4 \\
\text { mg administered } \\
\text { IV over } 15 \text { min; } \\
\text { pamidronate } 60-90 \\
\text { mg administered } \\
\text { IV over } 2-24 \text { h; } \\
\text { ibandronate } 2-6 \text { mg } \\
\text { administered IV } \\
\text { over } 1-2 \mathrm{~h}\end{array}$ & $\begin{array}{l}\text { Inhibition } \\
\text { of osteoclast } \\
\text { acitivity, } \\
\text { osteoclast } \\
\text { apoptosis and } \\
\text { improved } \\
\text { osteoblast } \\
\text { survival }\end{array}$ & $\begin{array}{l}\text { Zoledronic acid: Do not use } \\
\text { in patients with creatinine } \\
>4.5 \mathrm{mg} / \mathrm{dl} \text { (consider } \\
\text { increasing the infusion } \\
\text { duration in patients with } \\
\text { kidney disease); no need } \\
\text { for hepatic adjustment } \\
\text { Pamidronate and } \\
\text { ibandronate: Do not use if } \\
\text { glomerular filtration rate } \\
\text { is <30; no need for hepatic } \\
\text { adjustment }\end{array}$ & $\begin{array}{l}\text { Within } 2-4 \text { days } \\
\text { after administration. } \\
\text { Do not repeat } \\
\text { administration } \\
\text { earlier than } 1 \text { week } \\
\text { after the previous } \\
\text { IV infusion }\end{array}$ & $\begin{array}{l}\text { Flu-like } \\
\text { symptoms, bone } \\
\text { aches, nephrotic } \\
\text { syndrome, acute } \\
\text { kidney injury, } \\
\text { osteonecrosis of } \\
\text { the jaw }\end{array}$ \\
\hline Denosumab & $\begin{array}{l}120 \mathrm{mg} \\
\text { subcutaneously }\end{array}$ & $\begin{array}{l}\text { Impairs } \\
\text { osteoclast activity }\end{array}$ & $\begin{array}{l}\text { No need for renal and } \\
\text { hepatic adjustment. } \\
\text { Consider half dose for } \\
\text { patients with renal disease } \\
\text { to decrease the risk of } \\
\text { hypocalcemia }\end{array}$ & $\begin{array}{l}\text { Within } 2-4 \text { days } \\
\text { after administration. } \\
\text { Do not repeat } \\
\text { administration } \\
\text { earlier than } 1 \text { week } \\
\text { after the previous } \\
\text { dosing }\end{array}$ & $\begin{array}{l}\text { Bone pain, } \\
\text { nausea, diarrhea, } \\
\text { shortness } \\
\text { of breath, } \\
\text { osteonecrosis } \\
\text { of the jaw and } \\
\text { possibly increase } \\
\text { in the risk of } \\
\text { infections after } \\
\text { long-term use }\end{array}$ \\
\hline
\end{tabular}




\section{Conclusion}

Hypercalcemia of malignancy is a common finding typically in patients with advanced stage cancers. Hypercalcemia of malignancy usually presents with markedly elevated calcium levels and patients are therefore usually severely symptomatic. Several major mechanisms are responsible for the development of hypercalcemia of malignancy, including PTHrP-mediated humoral hypercalcemia, osteolytic metastases-related hypercalcemia, 1,25-dihydroxyvitamin D mediatedhypercalcemia, and PTH-mediated hypercalcemia in patients with parathyroid carcinoma and extra parathyroid cancers. Diagnosis should include the history of the patient and physical examination, as well as the measurement of the above mediators of hypercalcemia. Management includes IV hydration, calcitonin, bisphosphonates, denosumab, and prednisone and cinacalcet in certain patients. Patients with advanced underlying kidney disease and refractory severe hypercalcemia should be considered for hemodialysis. Hematology or oncology and palliative care specialists should be involved early on to guide the selection of cancer-targeted therapies and help the patients and surrogates with comfort care and discussing potential comfort care options.

\section{Financial support and sponsorship}

Nil.

\section{Conflicts of interest}

There are no conflicts of interest.

\section{References}

1. Endres DB. Investigation of hypercalcemia. Clin Biochem 2012;45:954-63.

2. Burt ME, Brennan MF. Incidence of hypercalcemia and malignant neoplasm. Arch Surg 1980;115:704-7.

3. Vassilopoulou-Sellin R, Newman BM, Taylor SH, Guinee VF. Incidence of hypercalcemia in patients with malignancy referred to a comprehensive cancer center. Cancer 1993;71:1309-12.

4. Stewart AF Clinical practice. Hypercalcemia associated with cancer. N Engl J Med 2005;352:373-9.

5. Ralston SH, Gallacher SJ, Patel U, Campbell J, Boyle IT. Cancer-associated hypercalcemia: Morbidity and mortality. Clinical experience in 126 treated patients. Ann Intern Med 1990;112:499-504.

6. Hamilton F, Carroll R, Hamilton W, Salisbury C The risk of cancer in primary care patients with hypercalcaemia: A cohort study using electronic records. Br J Cancer 2014;111:1410-2.

7. Soyfoo MS, Brenner K, Paesmans M, Body JJ. Non-malignant causes of hypercalcemia in cancer patients: A frequent and neglected occurrence. Support Care Cancer 2013;21:1415-9.

8. Gasparyan AY, Ayvazyan L, Blackmore H, Kitas GD. Writing a narrative biomedical review: Considerations for authors, peer reviewers, and editors. Rheumatol Int 2011;31:1409-17.
9. Bronner F. Mechanisms of intestinal calcium absorption. J Cell Biochem 2003;88:387-93.

10. Hall JE. Guyton and Hall Textbook of Medical Physiology. $12^{\text {th }}$ ed. Saunders, 2010; p. 955-972.

11. Mellis DJ, Itzstein C, Helfrich MH, Crockett JC. The skeleton: A multi-functional complex organ: The role of key signalling pathways in osteoclast differentiation and in bone resorption. J Endocrinol 2011;211:131-43.

12. Hofbauer LC, Schoppet M. Clinical implications of the osteoprotegerin/RANKL/RANK system for bone and vascular diseases. JAMA 2004;292:490-5.

13. Eghbali-Fatourechi G, Khosla S, Sanyal A, Boyle WJ, Lacey DL, Riggs BL. Role of rank ligand in mediating increased bone resorption in early postmenopausal women. J Clin invest 2003;111:1221-30.

14. Boyle WJ, Simonet WS, Lacey DL. Osteoclast differentiation and activation. Nature 2003;423:337-42.

15. Wysolmerski JJ. Parathyroid hormone-related protein: An update. J Clin Endocrinol Metab 2012;97:2947-56.

16. Akhtari M, Mansuri J, Newman KA, Guise TM, Seth P. Biology of breast cancer bone metastasis. Cancer Biol Ther 2008;7:3-9.

17. Johnson RW, Nguyen MP, Padalecki SS, Grubbs BG, Merkel AR, Oyajobi BO, et al. TGF-beta promotion of Gli2-induced expression of parathyroid hormone-related protein, an important osteolytic factor in bone metastasis, is independent of canonical Hedgehog signaling. Cancer Res 2011;71:822-31.

18. Roodman GD. Pathogenesis of myeloma bone disease. J Cell Biochem 2010;109:283-91.

19. Pearce CJ, Hine TJ, Peek K. Hypercalcaemia due to calcium binding by a polymeric IgA kappa-paraprotein. Ann clin biochem 1991;28(Pt 3):229-34.

20. VanHouten JN, Yu N, Rimm D, Dotto J, Arnold A, Wysolmerski JJ, et al. Hypercalcemia of malignancy due to ectopic transactivation of the parathyroid hormone gene. J Clin Endocrinol Metab 2006;91:580-3.

21. Tong CV, Hussein Z, Noor NM, Mohamad M, Ng WF. Use of denosumab in parathyroid carcinoma with refractory hypercalcemia. QJM 2015;108:49-50.

22. Hutchesson AC, Bundred NJ, Ratcliffe WA. Survival in hypercalcaemic patients with cancer and co-existing primary hyperparathyroidism. Postgrad Med J 1995;71:28-31.

23. Lee SH, Kim BH, Bae MJ, Yi YS, Kim WJ, Jeon YK, et al. Concurrence of primary hyperparathyroidism and metastatic breast carcinoma affected a parathyroid gland. J Clin Endocrinol Metab 2013;98:3127-30.

24. Hussain N, Khan M, Natarajan A, Mohammedabdul M, Mustafa U, Yedulla K, et al. A case of multiple myeloma coexisting with primary hyperparathyroidism and review of the literature. Case Rep Oncol Med 2013;2013:420565.

25. Inzucchi SE. Understanding hypercalcemia. Its metabolic basis, signs, and symptoms. Postgrad Med 2004;115:69-70, 73-6.

26. Nakajima N, Ueda M, Nagayama H, Yamazaki M, Katayama Y. Posterior reversible encephalopathy syndrome due to hypercalcemia associated with parathyroid hormone-related peptide: A case report and review of the literature. Intern Med 2013;52:2465-8.

27. Camara-Lemarroy CR, Gonzalez-Moreno EI, Ortiz-Corona Jde J, Yeverino-Castro SG, Sanchez-Cardenas M, Nuñez-Aguirre S, et al. Posterior reversible encephalopathy syndrome due to malignant hypercalcemia: Physiopathological considerations. J Clin Endocrinol Metab 2014;99:1112-6. 
28. Lins LE. Reversible renal failure caused by hypercalcemia. A retrospective study. Acta Med Scand 1978;203:309-14.

29. Caruana RJ, Buckalew VM Jr. The syndrome of distal renal tubular acidosis. Clinical and laboratory findings in 58 cases. Medicine Baltimore. 1988;67:84-99.

30. Gardner EC Jr, Hersh T. Primary hyperparathyroidism and the gastrointestinal tract. South Med J 1981;74:197-9.

31. Wynn D, Everett GD, Boothby RA. Small cell carcinoma of the ovary with hypercalcemia causes severe pancreatitis and altered mental status. Gynecol oncol 2004;95:716-8.

32. Diercks DB, Shumaik GM, Harrigan RA, Brady WJ, Chan TC. Electrocardiographic manifestations: Electrolyte abnormalities. J Emerg Med 2004;27:153-60.

33. Ashizawa N, Arakawa S, Koide Y, Toda G, Seto S, Yano K. Hypercalcemia due to Vitamin D intoxication with clinical features mimicking acute myocardial infarction. Intern Med 2003;42:340-4.

34. Nishi SP, Barbagelata NA, Atar S, Birnbaum Y, Tuero E. Hypercalcemia-induced ST-segment elevation mimicking acute myocardial infarction. J Electrocardiol 2006;39:298-300.

35. Turhan S, Kilickap M, Kilinc S. ST segment elevation mimicking acute myocardial infarction in hypercalcaemia. Heart 2005;91:999.

36. Kiewiet RM, Ponssen HH, Janssens EN, Fels PW. Ventricular fibrillation in hypercalcaemic crisis due to primary hyperparathyroidism. Neth J Med 2004;62:94-6.

37. Lafferty FW. Differential diagnosis of hypercalcemia. J Bone Miner Res 1991;6 Suppl 2:S51-9.

38. Ladenson JH, Lewis JW, McDonald JM, Slatopolsky E, Boyd JC. Relationship of free and total calcium in hypercalcemic conditions. J Clin Endocrinol Metab 1979;48:393-7.

39. Strodel WE, Thompson NW, Eckhauser FE, Knol JA. Malignancy and concomitant primary hyperparathyroidism. J Surg Oncol 1988;37:10-2.

40. Wong K, Tsuda S, Mukai R, Sumida K, Arakaki R. Parathyroid hormone expression in a patient with metastatic nasopharyngeal rhabdomyosarcoma and hypercalcemia. Endocrine 2005;27:83-6.

41. Bilezikian JP. Primary hyperparathyroidism. Endocr Pract 2012;18:781-90.

42. Kannan S, Milas M, Neumann D, Parikh RT, Siperstein A, Licata A. Parathyroid nuclear scan. A focused review on the technical and biological factors affecting its outcome. Clin cases miner bone metab 2014;11:25-30.

43. Gurney H, Grill V, Martin TJ. Parathyroid hormone-related protein and response to pamidronate in tumour-induced hypercalcaemia. Lancet 1993;341:1611-3.

44. Wimalawansa SJ. Significance of plasma PTH-rp in patients with hypercalcemia of malignancy treated with bisphosphonate. Cancer 1994;73:2223-30.

45. Pecherstorfer M, Schilling T, Blind E, Zimmer-Roth I, Baumgartner G, Ziegler R, et al. Parathyroid hormone-related protein and life expectancy in hypercalcemic cancer patients. J Clin endocrinol metab 1994;78:1268-70.

46. Ling PJ, A'Hern RP, Hardy JR. Analysis of survival following treatment of tumour-induced hypercalcaemia with intravenous pamidronate APD. Br J Cancer 1995;72:206-9.

47. Shivnani SB, Shelton JM, Richardson JA, Maalouf NM. Hypercalcemia of malignancy with simultaneous elevation in serum parathyroid hormone related peptide and 1,25-dihydroxy Vitamin D in a patient with metastatic renal cell carcinoma. Endocr Pract 2009;15:234-9.
48. Hosking DJ, Cowley A, Bucknall CA. Rehydration in the treatment of severe hypercalcaemia. Q J Med 1981;50:473-81.

49. LeGrand SB, Leskuski D, Zama I. Narrative review: Furosemide for hypercalcemia: An unproven yet common practice. Ann Intern Med 2008;149:259-63.

50. Vaughn CB, Vaitkevicius VK. The effects of calcitonin in hypercalcemia in patients with malignancy. Cancer 1974; 34:1268-71.

51. Dumon JC, Magritte A, Body JJ. Nasal human calcitonin for tumor-induced hypercalcemia. Calcif tissue Int 1992;51:18-9.

52. Wisneski LA. Salmon calcitonin in the acute management of hypercalcemia. Calcif tissue Int 1990;46(Suppl):S26-30.

53. Austin LA, Heath $\mathrm{H}^{\text {rd }}$. Calcitonin: Physiology and pathophysiology. N Engl J Med 1981;304:269-78.

54. Xu XL, Gou WL, Wang AY, Wang Y, Guo QY, Lu Q, et al. Basic research and clinical applications of bisphosphonates in bone disease: What have we learned over the last 40 years? J Transl Med 2013;11:303.

55. Russell RG, Xia Z, Dunford JE, Oppermann U, Kwaasi A, Hulley PA, et al. Bisphosphonates: An update on mechanisms of action and how these relate to clinical efficacy. Ann N Y Acad Sci 2007;1117:209-57.

56. Major P, Lortholary A, Hon J, Abdi E, Mills G, Menssen HD, et al. Zoledronic acid is superior to pamidronate in the treatment of hypercalcemia of malignancy: A pooled analysis of two randomized, controlled clinical trials. J Clin Oncol 2001;19:558-67.

57. Pecherstorfer M, Steinhauer EU, Rizzoli R, Wetterwald M, Bergström B. Efficacy and safety of ibandronate in the treatment of hypercalcemia of malignancy: A randomized multicentric comparison to pamidronate. Support care cancer 2003;11:539-47.

58. Gucalp R, Theriault R, Gill I, Madajewicz S, Chapman R, Navari R, et al. Treatment of cancer-associated hypercalcemia. Double-blind comparison of rapid and slow intravenous infusion regimens of pamidronate disodium and saline alone. Arch intern med 1994;154:1935-44.

59. Machado CE, Flombaum CD safety of pamidronate in patients with renal failure and hypercalcemia. Clin nephrol 1996;45:175-9.

60. Davenport A, Goel S, Mackenzie JC. Treatment of hypercalcaemia with pamidronate in patients with end stage renal failure. Scand J Urol Nephrol 1993;27:447-51.

61. Trimarchi H, Lombi F, Forrester M, Elizondo C, Sawinski D, Pereyra $\mathrm{H}$, et al. Disodium pamidronate for treating severe hypercalcemia in a hemodialysis patient. Nat clin pract nephrol 2006;2:459-63.

62. Saad F, Brown JE, Van Poznak C, Ibrahim T, Stemmer SM, Stopeck AT, et al. Incidence, risk factors, and outcomes of osteonecrosis of the jaw: Integrated analysis from three blinded active-controlled phase III trials in cancer patients with bone metastases. Ann oncol 2012;23:1341-7.

63. Hanley DA, Adachi JD, Bell A, Brown V. Denosumab: Mechanism of action and clinical outcomes. Int J Clin Pract 2012;66:1139-46.

64. Hu MI, Glezerman I, Leboulleux S, Insogna K, Gucalp R, Misiorowski W, et al. Denosumab for patients with persistent or relapsed hypercalcemia of malignancy despite recent bisphosphonate treatment. J Natl Cancer Inst 2013;105:1417-20.

65. Adhikaree J, Newby Y, Sundar S. Denosumab should be the treatment of choice for bisphosphonate refractory hypercalcaemia of malignancy. BMJ Case Rep 2014;2014. pii: bcr2013202861. 
66. Karuppiah D, Thanabalasingham G, Shine B, Wang LM, Sadler GP, Karavitaki N, et al. Refractory hypercalcaemia secondary to parathyroid carcinoma: Response to high-dose denosumab. Eur J Endocrinol 2014;171:K1-5.

67. Bech A, de Boer H. Denosumab for tumor-induced hypercalcemia complicated by renal failure. Ann Intern Med 2012;156:906-7.

68. Cicci JD, Buie L, Bates J, van Deventer H. Denosumab for the management of hypercalcemia of malignancy in patients with multiple myeloma and renal dysfunction. Clin lymphoma myeloma leuk 2014;14:e207-11.

69. Hu MI, Glezerman IG, Leboulleux S, Insogna K, Gucalp R, Misiorowski W, et al. Denosumab for treatment of hypercalcemia of malignancy. J Clin endocrinol metab 2014;99:3144-52.

70. Cummings SR, San Martin J, McClung MR, Siris ES, Eastell R, Reid IR, et al. Denosumab for prevention of fractures in postmenopausal women with osteoporosis. N Engl J Med 2009;361:756-65.

71. Adams JS. Vitamin D metabolite-mediated hypercalcemia. Endocrinol metab clin north am 1989;18:765-78.

72. Fardet L, Flahault A, Kettaneh A, Tiev KP, Généreau T, Tolédano C, et al. Corticosteroid-induced clinical adverse events: Frequency, risk factors and patient's opinion. Br J Dermatol 2007;157:142-8.

73. Collins MT, Skarulis MC, Bilezikian JP, Silverberg SJ, Spiegel AM, Marx SJ. Treatment of hypercalcemia secondary to parathyroid carcinoma with a novel calcimimetic agent. J Clin endocrinol metab 1998;83:1083-8.
74. Silverberg SJ, Rubin MR, Faiman C, Peacock M, Shoback DM, Smallridge RC, et al. Cinacalcet hydrochloride reduces the serum calcium concentration in inoperable parathyroid carcinoma. J Clin endocrinol metab 2007;92:3803-8.

75. Warrell RP Jr, Bockman RS, Coonley CJ, Isaacs M, Staszewski H. Gallium nitrate inhibits calcium resorption from bone and is effective treatment for cancer-related hypercalcemia. J Clin Invest 1984;73:1487-90.

76. Warrell RP Jr, Alcock NW, Bockman RS. Gallium nitrate inhibits accelerated bone turnover in patients with bone metastases. J Clin oncol 1987;5:292-8.

77. Hall TJ, Chambers TJ. Gallium inhibits bone resorption by a direct effect on osteoclasts. Bone miner 1990;8:211-6.

78. Warrell RP Jr, Israel R, Frisone M, Snyder T, Gaynor JJ, Bockman RS. Gallium nitrate for acute treatment of cancer-related hypercalcemia. A randomized, double-blind comparison to calcitonin. Ann Int Med 1988;108:669-74.

79. Cvitkovic F, Armand JP, Tubiana-Hulin M, Rossi JF, Warrell RP Jr. Randomized, double-blind, phase II trial of gallium nitrate compared with pamidronate for acute control of cancer-related hypercalcemia. Cancer J 2006;12:47-53.

80. Koo WS, Jeon DS, Ahn SJ, Kim YS, Yoon YS, Bang BK. Calcium-free hemodialysis for the management of hypercalcemia. Nephron 1996;72:424-8.

81. Leehey DJ, Ing TS. Correction of hypercalcemia and hypophosphatemia by hemodialysis using a conventional, calcium-containing dialysis solution enriched with phosphorus. Am J Kidney Dis 1997;29:288-90. 